\title{
The Correlation between Students' Performance in Integrated Exercises and Their Academic Achievements in English Course for Non-English Department
}

\author{
Qurinta Shinta \\ Universitas STEKOM, Semarang \\ qorinta@gmail.com \\ Article History: Submitted October $25^{\text {th }}, 2020$; Accepted December $23^{\text {rd }}, 2020$; \\ Published December $30^{\text {th }}, 2020$
}

\begin{abstract}
The English Course in Public Health Faculty of Diponegoro University is expected to develop the reading skills of the students through various exercises. However, its main goal is to help students identify simple, complex and compound sentences and how to organize them into good paragraphs. As in the Faculty of Public Health, the English Course is only given once in the first Semester, the exercises in each of the lesson is very compact which consists of Reading Text, Comprehension Questions, Word Study, Grammar and Usage, and Writing, in short these are called integrated exercised. Some students did very well on the exercises while others did not. The purpose of the study is to examine the relationship between the students' performance in integrated exercises and their academic achievements of Diponegoro University Students majoring in Public Health who took English Course. The academic achievements in this study refer to their Mid-Term test Scores. Method of the Study: in the study of Diponegoro University Freshmen majoring in Public Health, a descriptive qualitative method was used to determine whether or not there is a correlation between reading and writing exercises and their academic achievements. The instruments used are the scores of 3 taken from exercises in unit 1,2 and 3 and 1 Mid-Term test. The population of this research is 73 Public Health students of Diponegoro University taking English 1 Course. The data analysis result shows that Sig score is $0,000<0,05$ therefore Ho is declined and $\mathrm{Ha}$ is accepted, which means there is a correlation between reading and writing practices scores and mid test scores 0.403 which is positive. Therefore, it can be concluded that the higher their writing scores are, the higher mid test scores will be.
\end{abstract}

Key words: correlation, English course, integrated exercises, mid-term test

Abstrak. Mata kuliah Bahasa Inggris di Fakultas Kesehatan Masyarakat diharapkan mampu mengembangkan ketrampilan membaca mahasiswa memalui berbagai Latihan soal-soal. Namun, tujuan utama dari mata kuliah ini adalah membantu para mahasiswa menindentifikasi kalimat - kalimat sederhana, kompleks dan majemuk serta bagaimana membentuk kalimat - kalimat tersebut dalam bentuk paragraph. Karena mata kuliah Bahasa Inggris hanya disajikan satu kali, maka latihan-latihan soal pada setiap unit dibuat sangat padat yang terdiri dari Teks Bacaan, Pertanyaan tentang bacaan, Kosakata, Grammar dan fungsinya, serta Latihan writing. Ada mahasiswa yang bisa mengerjakan Latihan soal dengan sangat baik tetapi ada juga yang kesulitan. Tujuan dari peneltian ini adalah untuk melihat korelasi antara Nilai dari Latihan soal reading dan writing serta prestasi akademik dari Mahasiwa baru Universitas Diponegoro jurusan Kesehatan Masyarakat. Prestasi akademik dalam hal ini adalah nilai Mid-term test mereka. Dalam penelitian pada mahasiswa baru Universitas Diponegoro jurusan Kesehatan Masyarakat, digunakan metode deskriptif kualitatif untuk menetukan apakah ada atau tidak ada korelasi antara Latihan soal reading dan writing dengan prestasi akademik mereka. Instrumen yang digunakan pada penelitian ini adalah 3 nilai yang diambil dari 3 latihan soal Unit 1, 2 dan 3. Jumlah populasi adalah 73 Mahasiswa Kesehatan Masyarakat Universitas Diponegoro yang mengambil mata kuliah 
Bahasa Inggris 1. Hasil dari data analisis menunjukkan bahwa nilai Sig 0,000 < 0,05 sehingga Ho ditolak dan Ha diterima, yang berarti ada korelasi antara nilai Latihan writing dengan nilai ujian tengah semester 0.403 positif. Sehingga bisa disimpulkan bahwa semakin tinggi nilai mereka pada Latihan writing akan semakin tinggi juga nilai mereka dalam Ujian Tengah Semester.

Kata kunci: korelasi, mata kuliah bahasa Inggris, nilai latihan soal terpadu, nilai Ujian Tengah Semester

\section{INTRODUCTION}

In Indonesia English language teaching (ELT) for higher education such as in undergraduate level can be divided into two, as core subject (expertise subject) and as supporting (general) subject. ELT as core subject is found in English language department, whereas ELT for supporting subject (general subject) can be found in all non-English language Departments, based on the standard of content of 2010 Curriculum of Higher Education. (Akhiroh, Ninuk S, 2017:60)

ELT in higher education is presented differently from one University to another. Since it is based on the need of each university as well as its autonomy to design its own curriculum. This fact makes ELT in universities vary and the variation goes wider in the teaching of English for non-English majors. The variation includes teaching aim, management, material, credits, lecturers' qualification, number of students in a class, supporting facilities and many others (Sofendi, 2008).

In many non-English Department, the teaching of ELT is designed to meet fulfill its faculty need such as to introduce students English terminologies in their environment. This fact drives many ELT teacher to design ESP materials which are suitable for the faculty. Many ESP teachers in their researches reveal some typical problems in the implementation of ELT in universities such as the bad understanding on the nature of ELT among ELT stakeholders, lack of preparation, the unavailability of qualified teachers, and the very limited materials. (Akhiroh, Ninuk S, 2017:60)

Another research from Saleh (2018:81) concerning ELT for non-English Department revealed that that the materials should cover four skills of English Language and the should be given in various strategies with more emphasized on a competency-based vocabulary, this refers to the idea that learners are expected to understand a textbook material on other subjects which is very useful for them in job field through mastering the vocabulary.

Concerning ELT for Non English Department, a growing number of research has reported that number of universities that are offering ESP courses are on the rise recently to meet the increasing specific needs of students who come from different fields. (Javid, Choudhary Z. 2015:17). ESP courses (both academic and occupational) are created for the learners who need English for their occupation in post-academic setting or for those who need it for academic purposes in pre-occupational setting.

ESP teachers have to handle the extra burden of the content area of the learners as well. Moreover, ESP instructors have a challenging task because they are not in the position of 
being the 'primary knower' of the carrier content and even in most of the cases ESP learners may know more about the content than the teachers.

Other factors for the success of ELT for non-English Department students are Learners factor, age, attitudes, learning strategies and motivation (Javid, Choudary Z, 2015:19-20)

According to him, ESP learners are usually adults who have a strong educational background but have weaknesses in English. Dudley-Evans and St. John (1998) have also stated that ESP courses are usually designed for adult learners at "tertiary level" or for work place situations. Sifakis (2003, p. 2) has summarized "that all ESP learners (even non-adults) share adulthood-oriented characteristics". This well-defined goal-orientated behaviour of ESP learners increases interest and motivation. Therefore their motivation is based on practical needs: occupational, academic or financial.

The similar problems were also faced by English teachers in Diponegoro University who were supposed to teach non English Department students. They must deal with the problems such as fixed seating arrangement, larger classes, insufficient time allotment, and limited teaching materials.

In answering the above problems, the team English Department of Diponegoro University worked together to publish a book entitled "English for University Teaching - Freshman Level one and two" which is intended to be given for non-English Departments of Diponegoro University. This book has been designed to fulfill the students' needs in learning English at the University - as well as to give a standard English textbook (--, 2002 : vii).

Due to the general objectives of the book which is to develop the reading skill of the students through various exercises, they are also expected to increase their vocabulary. The grammatical exercises in this book are aimed to help increase the students' reading ability. Writing may be something luxurious for the students. However its main goal is to help students identify simple, complex, and compound sentences and how to organize them into good paragraphs (--, 2002: viii)..

It can be said that the exercises in this material were designed to accommodate all the skills in English Learning - except listening skill, namely Reading, Writing, and Speaking. In other word, they are integrated exercises. Each of the material unit follow the following format : Reading Text, Comprehension Questions, Word Study/Vocabulary, Grammar and Usage, and Writing.

The Reading Text is meant to give the students practices practice in reading for understanding for understanding. They must be able to get the main idea of the whole text as well as each of the paragraphs, which constitute the passage. Meanings of some of the difficult words are given under the Notes. Not all of the difficult words are provided with meanings, since students are expected to guess meanings from the context. The topics of the reading text are various from Borobudur Temple to Air Pollution to provide students with variety of vocabulary mastery.

Comprehension Questions are presented to check the students' comprehension of the whole passage. The types of questions can be in the form of information or question word questions, for which the students are trained to answer in complete sentences. Sometimes are asked in the form of Multiple Choice Questions, or in the form of True False Statements, 
for which students will simply have to indicate the correct answer after checking in the paragraphs.

Herewith are the example Reading Comprehension Questions taken from Reading Passage

"Borobudur and the Borobudur Tourist Park." ( --, 2002: 3-4)

B. Comprehension Questions

Exercise 1. Based on the reading above, answer the following questions

1) How is the land of Kedu Plateau?

2) What does the top Menoreh range on the southern flank resemble?

3) According to the folk tale, who is Gunadharma?

4) What kind of atmosphere can be created in Borobudur and its environments?

5) Where is Borobudur precisely located?

6) How large is the area of Tourist Park?

7) What does the Park comprise?

8) What trees are planted in the Park?

Exercise 2 Indicate if each statement is True $(\mathrm{T})$ or False $(\mathrm{F})$

1. $\mathrm{T} / \mathrm{F}$ Borobudur Tourist Park is to entertain the growing number of visitors and to preserve the natural environment of the temple.

2. T/F The Park was formally dedicated to President Suharto on February 23, 1983.

3. T/F The trees and flowers planted there include durian, coconut, apple, tulip and jasmine.

4. T/F The Museum consists of a research centre, on information centre and a temple park office.

5. T/F Information and pictures of Borobudur can be obtained in the temple museum.

Exercise 3 In each item, select the best meaning of the italicized word or phrase

1) One destination which attract tourists to visit this town is its oldest monument.
a. Entertainment
b. Temple
c. Journey's end
d. Destiny

2) The post office is located near the National Bank.
a. situated
b. replaced
c. removed
d. localized

3) There is a model of Borobudur reconstruction area. 

a. picture
b. show
c. demonstration
d. miniature

4) The classroom is provided with facilities such as stereo sound system.
a. equipped
b. full
c. comprised
d. given

5) The farmers in this village are friendly and industrious.
a. Industrial
b. Modern
c. Sluggish
d. Hard-working

6) In the cultural sentre, visitors may obtain information concerning the weekly events.
a. knowledge
b. science
c. leaflet
d. accomodation

Word Study section is meant to enrich the students' vocabulary which will enable them to read more and more difficult passages. They may be asked to identify the meanings of difficult words by using choice questions or filling up blanks with appropriate words taken from a list of choices. Sometimes they may be asked to list words belonging to the same or different categories, to identify the synonyms or antonyms of a given words, or to identify the part of speech of a word from a context.

Herewith are the examples of exercises to measure students' level of vocabulary taken from Unit 1 "Borobudur and the Borobudur Tourist Park". (--, 2002: 4-6)

\begin{tabular}{|c|c|c|c|}
\hline \multicolumn{4}{|c|}{$\begin{array}{l}\text { Write the existing corresponding words in the following box } \\
\text { Number one has been done for you }\end{array}$} \\
\hline Noun & verb & Adjective & Adverb \\
\hline 1. Nature & Naturalize & Natural & naturally \\
\hline 2. $\ldots \ldots \ldots \ldots$ & Fertilize & $\ldots \ldots \ldots \ldots \ldots \ldots$ & $\ldots \ldots \ldots \ldots \ldots \ldots$ \\
\hline 3. $\ldots \ldots \ldots \ldots \ldots$ & $\ldots \ldots \ldots \ldots \ldots$ & creative & ............... \\
\hline 4. Tranquility & ............. & $\ldots \ldots \ldots \ldots \ldots \ldots \ldots$ & ............... \\
\hline $5 \ldots \ldots \ldots \ldots \ldots$ & ............... & .................. & publicly \\
\hline $6 . \ldots \ldots \ldots \ldots \ldots$ & include & $\ldots \ldots \ldots \ldots \ldots \ldots \ldots$ & \\
\hline $7 . \ldots \ldots \ldots \ldots \ldots$ & & industrious & \\
\hline
\end{tabular}


Exercise 2 Circle the word that belongs to the same category as the words in the lefthand column

\begin{tabular}{|l|l|l|l|l|}
\hline People & temple & mountain & tourist & monument \\
\hline Place & nose & minibus & Rice-field & hectare \\
\hline Occupation & Plant & plateau & park & teacher \\
\hline Flower & jasmine & coconut & buffalo & cotton \\
\hline Measurement & laboratory & Dutch & kilometre & transportation \\
\hline Writing pad & lips & paper & hill & language \\
\hline
\end{tabular}

Exercise 3 in the space at the left, copy the word that is the verb of the italicized subject. Number one has been done for you.

...is ....... 1. The first day of registration for next semester is Tuesday.

2. Unfortunately, only a few of the standard rooms remain.

3. Your experience certainly qualifies you for the job.

4. Eleven of the seats in the class are empty.

5. Here comes the famous traveler with her video camera.

6. Two of the boys playing in the park are my children.

7. The women earn their incomes from small scale fish trading.

Taken from English for University Teaching

Grammar and Usage section introduces one grammatical point at time, for instance the use of Present Tense or Present Perfect Tense. Short explanatory remarks are presented are presented on the functions or meanings of the grammatical point in question with some examples. This will be followed by their forms, for instance, how to form the Present Perfect Tense. Thus the students will understand the meaning or function of the tense and how it is formed to express it. This explanation is followed by several exercises on grammar or other language usage which concern idioms or other set of expressions.

Herewith are the examples of Grammar And Usage : Simple Present Tense from Unit 1 ( --: 2002:7-8)

Simple Present Tense is used to talk about

a) things that happen habitually or repeatedly, e.g. The earth goes round the Sun.

b) facts, or general truths that stay the same for a long time, e.g. I live in Central Java.

c) Feelings, verbs expressing emotional state, e.g. I like, I want, etc

d) Mental perceptions, e.g. I think, I know

Exercise 1 Underline the correct answers in parentheses by using the simple present Tense.

1. They (make/making/are made) their living mainly from agriculture.

2. Cultivating rice or tobacco (has been/ had been/ is ) common to farmers in Java. 
3. Tourists can (visit/ visited/ be visited) Borobudur throughout the year.

4. The tourist park (is comprising/ comprises/ has comprised) a wide grassy area, trees, and fancy plants.

5. The reconstruction centre (consisting/consist/consists) of a laboratory and workshops.

Exercise 2 Choose the word or phrase that best completes the following sentences.

1) The usual flower can be found in the virgin forest.
a. the heart of
b. the top of
c. the heart to
d. the top on

2) Java island is famous its fertility.
a. on
b. to
c. for
d. by

3) According his mother, Bandu gets up early in the morning.
a. to
b. for
c. up to
d. on

4) The recreation area near my house is provided a swimming pool.
a. by
b. to
c. with
d. on

5) The two researchers observed the ceremony from the temple.
a. the top of
b. on top over
c. behind in
d. the back by

Exercise 3 Complete the sentences by using one of these verbs in the simple present tense : include, lie, tell, hire, make, provide, create, talk

1) This plateau in the heart of the island.

2) The temple and its surroundings an atmosphere of peace and tranquility.

3) They visitors with general public facilities.

4) The trees planted in the park coconut and durian trees.

5) People of this region their living from tourism.

6) You may a motor cycle for Rp. 9.000,- per hour. 
Writing Section is meant to develop the student's writing skill, beginning from writing simple sentences, to complex, compound, complex compound sentences, paragraphs, and later essays. The actual goal however, is not really the acquisition of the writing skill itself, but the students' ability in recognizing the arrangement of sentences into paragraphs and essays together with their sentences into paragraphs and essays together with their sentence linkers or sequence signals to show coherence in expression (--, 2002:ix)

Herewith are the writing exercises from unit 1 ( --, 2002:9-10)

Exercise 1 Match each of the items in the left-hand column with the appropriate item in the right-hand column in order to have correct and complete sentences.

\begin{tabular}{|l|l|}
\hline 1) The location of Borobudur & is believed to be the architect of the temple \\
\hline 2) Kedu Plateau & includes buses and minibuses \\
\hline 3) The Top of Menoreh range & is famous for its fertility \\
\hline 4) Gunadharma & is in Magelang area \\
\hline 5) Public Transportation & $\begin{array}{l}\text { resembles the nose, lips, and chin of a } \\
\text { supine figure }\end{array}$ \\
\hline
\end{tabular}

Exercise 2 Put the following words or phrases into correct sentences

1) a local folktale - the man - is - according to - reclining - there - Gunadharma

2) officially - February 23, 1983 - the tourist park - opened - on - President Suharto

3) Borobudur temple - a model of - in the museum - there is

4) are - friendly - and - this region - industrious - the people of

5) attracts - many tourists - the temple - to the area

Exercise 3 Write sentences in the simple present tense by using the following words

1) visit

2) stretch from

3) lead to

4) accommodate

5) adjacent to

6) concerning

7) carry on

8) inform

Taken from English for University Teaching

\section{Grammatical Points and Themes}

Since High School graduates who enter the university are generally still very poor in their English Mastery, it is considered imperative to review all the English Grammar in general and English tenses in particular from the very beginning. There will be thus special treatments, for instance, on the use of the Simple Present Tense, The Simple Past tense, The Present Continuous Tense, The Present Perfect Tense, etc. In order not to bore the students with dry an uninteresting treatment of grammar the students should be more encouraged to use English to communicate about their field of study or interest. Therefore, the twelve 
lesson units in Book-1 should be dealing with variety of themes, which may interest the students. The following list of themes has been chosen, for instance, to be presented in Book -1 together with the grammatical points to be developed.

\begin{tabular}{|l|l|l|}
\hline No & \multicolumn{1}{|c|}{ Theme } & \multicolumn{1}{c|}{ Grammar Point } \\
\hline 1. & Tourism & Simple Present \\
\hline 2. & Legend & Past Continuous \\
\hline 3. & Economy & Simple Continuous \\
\hline 4. & Ancient Cult & Passive Voice \\
\hline 5. & Popular Science & Present Perfect tense \\
\hline 6. & Population Growth & Present vs Past Participle \\
\hline 7. & Literature & Adjective vs. Adverb \\
\hline 8. & Food Preservation & Degree of Comparison \\
\hline 9. & Law & Phrases \\
\hline 10. & Crime & Going to vs will \\
\hline 11. & Development & Gerund vs Infinitive \\
\hline 12. & Health & Relative Clause \\
\hline
\end{tabular}

Taken from English for University Teaching

In order that the reading texts become interesting to the students certain criteria have to be applied in selecting them. Firstly, the content should be familiar to the students. For instance, they must be picked out from their own fields of study, which are usually taught in their departments such as medicine, economics, tourism, public health, etc. Or they can also be taken from their own environment or experience; so the technique of growing rice or a trip to Borobudur would be very familiar to the students. If they are asked to communicate about them there may be some difficulty in using the language, but certainly not in the content of communication. Therefore the materials are taken from such authentic sources as newspapers, magazines or bulletins published by companies or government offices.

Another criterion to be taken into account is the difficulty level of the language used in the text, which more or less suits the students' mastery of English. It should not be too difficult to reawaken their interest in studying English. On the other hand, the language should not be too easy or else the students tend to look down upon it. They may also lose interest in reading the text because it is not challenging enough (--, 2002:x)

Since English Course is only given in first semester in almost every non English Departments in Diponegoro University - including in Public Health Faculty, only Level one is used in the teaching and learning process. English I Course consists of 12 topics in which each topic covers many language functions such as reading passage - questions about the passage, vocabulary exercise, grammar exercise, and sentence writing. In order to encourage students to be able to understand better, students are asked to practice writing which started from simple sentences until essay writing. The goal of writing practices is to help them perform well in their test (mid test).

Based on the above problem, therefore the writer is interested in conducting a research entitled "The Correlation between Students' Integrated Practices and Their Academic Achievements."

There are two problem statements in this study: 1. Is there any correlation between students integrated practices scores and their academic achievements? 2. If there is a correlation - is 
it significant? This study is limited to: 73 Public Health students of Diponegoro University Semarang taking English I Course. While the scores included 3 scores in integrated practices dan 1 score in mid test.

This study is expected to answer the hypotheses as follows: 1 . There is a correlation between the scores of integrated practices and the scores of mid test. 2.There is no correlation between the scores of integrated practices and the scores of mid-term test.

The purpose of the study is to discover whether there is a correlation between integrated Practices and students' academic achievements of Public Health of Diponegoro University Semarang taking English 1 course.

\section{METHOD}

\section{Research Method}

This research applied a descriptive quantitative method. The method refers to research method which is based on positivism philosophy, and it used to study a certain population or sample, data collection by using research instruments, analysis on quantitative/statistics data in order to test the hypotheses stated before.

\section{Sampling and Sampling Techniques}

There are several techniques of sampling, random sampling, cluster sampling, purposive sampling, stratified sampling, area sampling, double sampling and proportional sampling (Arikunto, 2007:95-97). This research used purposive sampling technique, in which the respondents were 73 Diponegoro University Students majoring in Public Health who took English I Course based on the feasibility of access and time limitation. The rationale for these research respondents is that the students in this research are not divided into genders (male and females) since the number of males in this class is insignificant (less than 10) and since the practices are given during the teaching and learning process, each student has the same duration of time and opportunity to finish them by accessing other media or even asking other classmates every time they face difficulties.

\section{Instruments and Data Collection}

This research used two kinds of instruments to collect data: 1. Integrated Practice Scores integrated Practices was conducted during the semester, and three (3) scores were chosen based on the variety of the tasks. 2. Mid Test Scores. Mid Test (1x) is a test that was conducted in the mid semester to measure students understanding of the course. Mid test score in English 1 contribute 30\% of the score evaluation by the end of the semester. The three scores of integrated practices were compared to mid test scores to measure whether there is any significant correlation between these two kinds of scores. 
DAFTAR NILAI MAHASISWA FKM - UNDIP

Semester GanjII Tahun Akademik 2019/2020

Nama Mata Kullah

Semester / sks
Bahasa Inogris

$1 / 2$

Dosen : Dra. Qorlinta Shinta, M.Hum.

Jurusan: Fakultas Kesehatan Masyarakat Undp Group B

\begin{tabular}{|c|c|c|c|c|c|c|}
\hline \multirow{2}{*}{ NO } & \multirow{2}{*}{ NIM } & \multirow{2}{*}{ Nama } & \multicolumn{3}{|c|}{ Nellat Tugas Unit } & \multirow[b]{2}{*}{ NIllal UTS } \\
\hline & & & 1 & 2 & 3 & \\
\hline 1 & 20053 & Kania We Hapani & as & 73 & $\infty$ & $n$ \\
\hline 2 & 30203 & Adhinna Putri Rachmaningrum & as & so & $\infty$ & $\pi e$ \\
\hline 3 & 30200 & 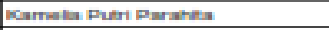 & Bo & 80 & as & $\pi \mathrm{s}$ \\
\hline 4 & 40201 & Nivbla Mirharant Wigura & as & 60 & 80 & 38 \\
\hline 3 & 40258 & Sarndra Derrika Auturt & Bo & 80 & 80 & $\pi$ \\
\hline e & 40263 & Amilia Mutnh & as & $\infty$ & $\infty$ & $\pi \mathrm{s}$ \\
\hline 7 & 30217 & Frow Teamara Shona & Do & $\infty$ & $\infty$ & $\infty$ \\
\hline$a$ & 400230 & Narida Putri Desmani & 90 & 8 & 80 & 63 \\
\hline 2 & 40330 & Mun Bagus Catyong & 90 & 60 & $\infty$ & so \\
\hline 10 & 40338 & Cutharine Nobaris Sethant & as & 75 & $\infty$ & 91 \\
\hline 11 & 40311 & 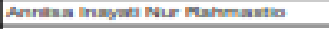 & as & $\infty$ & as & 63 \\
\hline 12 & 40317 & Ehidarna Milnati Harituh & Bo & $\infty$ & $\infty$ & та \\
\hline 13 & 40323 & Pantya Indiah Fontapes & as & 20 & as & sa \\
\hline 14 & 40200 & Dutan Manan Murtaq & as & 80 & $\infty$ & $\pi$ \\
\hline 15 & $4002 \pi 5$ & 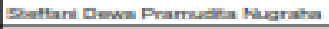 & as & $\infty$ & $\infty$ & $\pi \mathrm{s}$ \\
\hline 16 & 30123 & 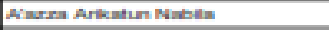 & as & $\infty$ & 80 & $\infty$ \\
\hline 17 & 30120 & Paulicya Fonart Sirsogr & as & $\infty$ & 80 & $\mathbf{\infty}$ \\
\hline 18 & 30138 & 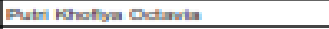 & as & 80 & 80 & $\pi e$ \\
\hline 19 & 20003 & 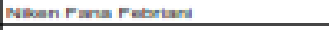 & $T s$ & 80 & 75 & $\pi e$ \\
\hline 20 & 20041 & Gamin Wust Adthytan & 60 & 73 & as & 59 \\
\hline 21 & 20047 & Lira Nund Oolnish & as & $\infty$ & $\infty$ & ne \\
\hline 22 & 30001 & Dien Aulina Nurtbaety & Bo & $\infty$ & as & Te \\
\hline 23 & 30007 & Fals.Aohnia Chimani & as & $\infty 0$ & $\infty$ & mos \\
\hline 24 & 30003 & Fimi Mahmuedtam: & 90 & 80 & as & $\pi$ \\
\hline 28 & 20009 & Ceetby Neeta Autarna & Ts & 80 & 80 & 3 \\
\hline $2 \pi$ & 20000 & Fineta Mai Aatus & Bo & $\infty$ & as & 41 \\
\hline $2 \pi$ & 30000 & 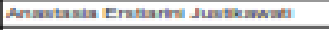 & Bo & $\infty$ & $\infty 0$ & 30 \\
\hline 20 & 30908 & Mule Wistryuningath & 90 & so & as & ne \\
\hline 29 & 30111 & Nonrina Oetalta Chumar & as & 80 & 80 & $\infty$ \\
\hline 30 & 30117 & Demol Purnammanat & as & 80 & 80 & 52 \\
\hline 31 & 40360 & Angai Murmeriani Zan & 80 & $\infty$ & 75 & $\infty 0$ \\
\hline 32 & 40371 & 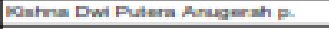 & as & 80 & $\infty$ & $\infty$ \\
\hline 30 & 40377 & Marian Mutieran Mahed & as & 80 & as & 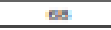 \\
\hline 34 & 40383 & Aurdy Ananita Fontinualdy & Bo & 80 & 75 & 83 \\
\hline 30 & 30177 & Aprta Suanti & as & $\infty 0$ & $\$ 0$ & $\infty$ \\
\hline 30 & 30583 & Aminta Solnktuas & as & $\infty$ & $\infty$ & os \\
\hline 39 & 40380 & 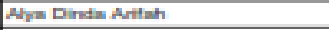 & as & 80 & as & 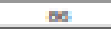 \\
\hline 30 & 40413 & 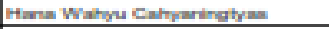 & as & 80 & as & Dos \\
\hline 30 & 30965 & Nina Matankiah & as & $\infty 0$ & $\infty$ & 84 \\
\hline 40 & 30171 & 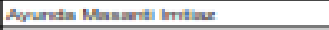 & as & 80 & 80 & $\infty$ \\
\hline 41 & 40347 & Nurkhadinam Matharie & Bo & 80 & as & $\infty$ \\
\hline 42 & 40353 & Mdya Patmi Irant: & as & $\infty$ & $\infty 0$ & $\infty 3$ \\
\hline 43 & 40350 & Linda Matranant & as & 90 & $\infty$ & 57 \\
\hline 44 & 30541 & 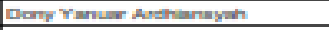 & Bo & 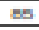 & $\infty$ & $\infty$ \\
\hline 45 & 30947 & Murki Aulta Putri Aulis & as & 80 & as & $\pi e$ \\
\hline 46 & 20021 & Novinitan Dwi.Anoles & 80 & 79 & $\infty$ & $\infty$ \\
\hline 47 & 20027 & Agrimen Tiara Simanuling & Bo & 80 & $\infty$ & so \\
\hline 40 & 40248 & Mamena Nur Amala & Bo & 80 & as & 6s \\
\hline 40 & 400251 & Aveu Fatmandiants & $T S$ & 60 & 60 & $=0$ \\
\hline so & 300231 & Pinta Andlyant & Bo & $7 s$ & as & $\pi 8$ \\
\hline st & 30153 & Ulya Sintiq Satila & as & $\infty$ & as & m \\
\hline 52 & 30150 & 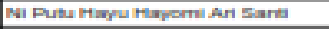 & 90 & 80 & $\infty$ & $\infty$ \\
\hline 50 & 40293 & 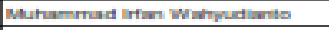 & 60 & 79 & 60 & 3 \\
\hline se & 40290 & Mevinha Marrarindita & as & 75 & $\infty$ & $\pi$ \\
\hline 30 & 40300 & 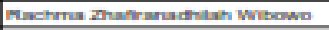 & as & 60 & 80 & 53 \\
\hline 50 & 40285 & Dyafina Armain Utamt & Bo & 60 & as & no \\
\hline $5 \pi$ & 40287 & Faze Talthe Singry & as & $\infty$ & $\infty$ & -5 \\
\hline 50 & 30100 & Luthatun Nesa & Do & 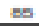 & $\infty$ & $\pi 3$ \\
\hline
\end{tabular}

\begin{tabular}{|c|c|c|c|c|c|c|}
\hline 50 & 30105 & Anyadirani Mauharmenya & 60 & 80 & as & 5 \\
\hline 60 & 20090 & Pratia Cetby Authaquma & as & 75 & 80 & 61 \\
\hline 61 & $300 \mathrm{rs}$ & Avifin Tajman Ekaviand & as & 80 & 75 & es \\
\hline 02 & 20067 & Eleims Nabiho & as & 80 & 80 & $\infty$ \\
\hline E4 & 30177 & Mamadhina Nur Paura & 80 & 80 & 80 & re \\
\hline$e s$ & 20053 & Panka indriyani & as & 75 & as & 51 \\
\hline 60 & 20056 & Pathyouh Desya Mranty & 75 & 75 & 60 & $\mathbf{m o}$ \\
\hline 60 & 40121 & Lasa Petrilyanti & $T S$ & 75 & 60 & $\Leftrightarrow$ \\
\hline 60 & 40154 & Moso Zmmara & Bo & 20 & 60 & $\pi 2$ \\
\hline$\pi 0$ & 140182 & Des Aguntin Nonamati & 75 & 75 & 60 & $\pi 0$ \\
\hline$\pi$ & 20006 & Saluatiela Farthanum & Bo & 80 & $\infty$ & sa \\
\hline$\pi$ & 20007 & Sutrm Dyanim & Bo & 80 & $\infty$ & sa \\
\hline$\pi$ & 30213 & Mala Predent latast & Bo & 60 & $\infty$ & 4 \\
\hline
\end{tabular}

Taken from primary data 


\section{Data Analysis}

The data were then analyzed by using the following tests:

\section{Normality Test}

Normality Distribution Test is a test to measure whether certain data are distributed normally or not, therefore they can be used in inferential statistics.

The Hypotheses used are

$\mathrm{H}_{0}$ : data with normal distribution

$\mathrm{H}_{1}$ : data with abnormal distribution

The test procedures were as follows

(1) Determining $F_{0}(X)$ : Theoretical cumulative distribition which was expected below $H_{0}$.

(2) Setting scores to be observed in a cumulative distribution by pairing each interval $S_{N}(X)$ with the equivalent interval $F_{0}(X) . S_{N}(X)$ was the cumulative distribution frequency of data which was observed from a random sample with $N$ observation. In which $X$ any possible random score. a $S_{N}(X)=\frac{k}{n}$, in which $\mathrm{k}=$ the number of observations which was the same or less than $X$.

(3) For each level, $F_{0}(X)-S_{N}(X)$. Below $H_{0}$, it was expected that the value of $X$, $S_{N}(X)$ should be close to $F_{0}(X)$. This means that the difference between $S_{N}(X)$ and $F_{0}(X)$ was low and within random error boundaries.

(4) Calculate D (deviation) with the following formula $D=\operatorname{maximum}\left|F_{0}(X)-S_{N}(X)\right|$

Looking at table E to find out possibilities (two sides) which was correlated with the existence of values as much as the value of observation $\mathrm{D}-$ below $H_{0}$.

If $D_{\text {count }} \geq \frac{1,36}{\sqrt{N}}$, in which $N$ is test participant, so $H_{0}$ is rejected (Siegel, 1994). Hypotheses test for this research by considering the criteria if sig value $<0,05$, therefore $\mathrm{H}_{0}$ is rejected (Santoso, 2002).

\section{Correlation Test}

The correlation Test is conducted between Writing Practices Score and Mid Test Scores by using Spearman Rank Correlation Test.

Hypotheses:

Ho: Writing Practices scores and Mid Test Scores have no correlation

Ha: Writing Practices scores and Mid Test Scores are correlated.

The formula used to test Spearman Rank Correlation is : 
$r s=1-\frac{6 \sum d^{2}}{n\left(n^{2}-1\right)}$

If $\mathrm{rs}>\mathrm{rs}$ table, Ho is rejected and Ha is accepted (Sugiyono, 2007). Test of Hypotheses in this research by considering value sig $<0,05$, therefore Ho is rejected and Ha is accepted.

\section{RESULTS AND DISCUSSION}

\section{Results}

The Result of Normality test on Writing Practices and Mid Test Scores can be seen on Table 1 .

Table 1 One-Sample Kolmogorov-Smirnov Test

\begin{tabular}{|c|c|c|c|}
\hline & & writing & uts \\
\hline$N$ & & 73 & 73 \\
\hline \multirow[t]{2}{*}{ Normal Parameters ${ }^{a}$} & Mean & 79.8082 & 67.5753 \\
\hline & Std. Deviation & 6.04993 & 1.54263E1 \\
\hline \multirow[t]{3}{*}{ Most Extreme Differences } & Absolute & .176 & .105 \\
\hline & Positive & .088 & .051 \\
\hline & Negative & -.176 & -.105 \\
\hline Kolmogorov-Smirnov Z & & 1.501 & .895 \\
\hline Asymp. Sig. (2-tailed) & & .022 & .399 \\
\hline a. Test distribution is Norm & & & \\
\hline
\end{tabular}

Writing Score Data is sig 0,22<0,05, therefore it isn't normally distributed . Mid test Score Data is sig $0,399<0,05$ therefore it is normally distributed

One of the data is not normally distributed, therefore correlation test uses non parametric statistics which is Spearman Rank Correlation Test.

The result of Correlation Test by using Non Parametric Statistics is shown in Table 2.

Table 2 Correlations

\begin{tabular}{|c|c|c|c|c|}
\hline & & & writing & uts \\
\hline \multirow[t]{2}{*}{ Spearman's rho } & writing & $\begin{array}{l}\text { Correlation Coefficient } \\
\text { Sig. (2-tailed) } \\
\mathrm{N}\end{array}$ & $\begin{array}{r}1.000 \\
73\end{array}$ & $\begin{array}{r}.403^{* *} \\
.000 \\
73\end{array}$ \\
\hline & uts & $\begin{array}{l}\text { Correlation Coefficient } \\
\text { Sig. (2-tailed) } \\
\mathrm{N}\end{array}$ & $\begin{array}{r}.403^{* *} \\
.000 \\
73\end{array}$ & $\begin{array}{r}1.000 \\
73\end{array}$ \\
\hline
\end{tabular}

${ }^{* *}$. Correlation is significant at the 0.01 level (2-tailed). 
Sig value $0,000<0,05$ therefore Ho is rejected and Ha is accepted. It can be concluded that writing practices and Mid test are correlated. The correlation between Writing Practices and Mid Test is 0,403 which is positive. Therefore, the higher students' writing ability - the higher their score in Mid Tests and vice versa.

\section{Discussion}

The study reveals that there is a correlation between integrated practices and mid-term test scores. This implies that intensive practices will result in students' motivation to read more, to enhance their vocabulary, as well as to broaden their knowledge that eventually will affect their achievement in doing the mid test. This research is also supported by a study conducted by Saleh (2018:81) concerning ELT for non-English Department, it revealed that that the materials should cover four skills of English Language and the should be given in various strategies with more emphasized on a competency-based vocabulary, this refers to the idea that learners are expected to understand a textbook material on other subjects which is very useful for them in job field through mastering the vocabulary.

Other factors for the success of ELT for non-English Department students are Learners factor, age, attitudes, learning strategies and motivation (Javid, Choudary Z, 2015:19-20)

This well-defined goal-orientated behaviour of ESP learners increases interest and motivation. Therefore their motivation is based on practical needs: occupational, academic or financial. Sifakis (2003, p. 2) has concluded "that all ESP learners (even non-adults) share adulthood-oriented characteristics". In short, in can be concluded that their motivation is based on practical needs: occupational, academic or financial.

\section{CONCLUSION}

Based on the tests, it can be summarized that: 1.There are positive correlation between students' performance in integrated practices and their academic achievements (in this case shown in score of mid test). The higher their scores in integrated practices, the higher mid test scores they get. 2 . It can be concluded that that there is a correlation between scores in integrated practices and students' academic achievements (mid test scores).

However, due to the big number of students in the class, as well as the complexity of the exercises the author was only able to take three exercises as research samples. Since correcting all the exercises was extremely time consuming. Moreover, due the time limitation sometimes not all materials in one unit can be completed in one teaching learning process.

There are two recommendations for this research: 1. This type of research should be implemented in a broader scope (more subjects and students from many classes) in order to get a more valid result. 2. School Institution needs to enlarge extracurricular activities to encourage students to have reading interest within themselves, which eventually result in improvement of their academic achievements.

\section{REFERENCES}

A Team of Writers. (2002). English for University Teaching: Freshmen; Level One \& two. Badan Penerbit Universitas Diponegoro 
Akhiroh, N. S. . (2017). Teaching English in Non-English Departments: Empowering Teacher Towards Improvement. IJEE (Indonesian Journal of English Education), 4(1), 49-62. doi:10.15408/ijee.v4i1.5341

Arikunto, Suharsimi. (2007). Manajemen Penelitian. Jakarta : Rineka Cipta

Harmer, Jeremy. (2003). The Practice of English Language Teaching - third Edition Completely Revised and Updated. England : Pearson Education Limited.

Javid, C. Z. (2015). English for Specific Purposes: Role of learners, teachers, and teaching methodologies. European Scientific Journal, 11(20). Retrieved from https://eujournal.org/index.php/esj/article/viewFile/.

Saleh, Yuwin, R. (2018) Need Analysis in Learning English for Non English Program at Tarbiyah and Teacher Training Faculty. Journal al-LisanJournal al-Lisan ISSN 24428965 \& E ISSN 2442-8973 Volume 3 Nomor 2 - Agustus 2018 http://journal.iaingorontalo.ac.id/index.php/al

Santoso, S. 2002. Buku Latihan SPSS Statistik Parametrik. Jakarta: PT.Elex Media Komputindo

Siegel, S. 1994. Statistic Nonparametrik untuk Ilmu-ilmu Sosial. Jakarta: PT. Gramedia Pustaka Utama

Sifakis, N. C. (2003). Applying the adult education framework to ESP curriculum development: an integrative model. in: Science Direct, English for Specific Purposes, 22(2):195211.http://www.sciencedirect.com/science? ob=ArticleURL\& udi=B6VD M45FGWX21\&_user=1723672\&_rdoc $=1 \&$ fmt $=$ \&_orig $=$ search\&_sort $=$ d\&_doc anchor $=\&$ view $=c \& \_s e a r c h S t r I d=948957940 \& \_r e r u n O r i g i n=$ google $\& \_a c c t=C 0000$ 52544\&_version $=1 \&$ _urlVersion $=0 \& \_u s e r i d=1723672 \& \mathrm{md} 5=\mathrm{d} 68660272 \mathrm{f0dbdffbc} 4$ b2606ea902676

Sofendi. (2008). Tujuan pengajaran bahasa Inggris di Universitas Sriwijaya. Paper presented on "Seminar dan Rapat Tahunan ke-4 BKS-PTN Wilayah Barat Bidang Bahasa Tahun 2008”. Retrieved from www.eprints.unsri.ac.id on 8/11/2016.

Sugiyono. 2007. Statistika untuk Penelitian. Bandung: CV Alfabeta 